\title{
Profit Sharing Risk: Accountability Values In Local Cattle Sharing System
}

\author{
${ }^{1}$ PRASETYONO, ${ }^{2}$ YULIANA RAKHMAWATI, ${ }^{3}$ ACH FAWAID AS'AD, ${ }^{4}$ ERFAN \\ MUHAMMAD
}

\author{
Universitas Trunojoyo Madura, Bangkalan, Indonesia \\ e-mail: ${ }^{1}$ prasetyono_akt@trunojoyo.ac.id; ${ }^{2}$ yuliana.r@trunojoyo.ac.id; ${ }^{3}$ fhawaid01@gmail.com; ${ }^{4}$ erfan94@ \\ yahoo.com
}

\begin{abstract}
Beef cattle's sharing is an Indonesian traditional economic system that is formed naturally based on local wisdom values. Even though it is done traditionally, the principles of good cooperation have been practiced. Based on that, this research aims to describe the economic perspective, particularly the accountability values embedded in Indonesia's local cattle sharing system. This research employs a case study to obtain the accountability values in two local, regional cattle sharing locations in Java and Madura. Informants of this research are local cattle farmers, investors, and middlemen. Data analysis uses a single case-multilevel analysis method. The study results show that Javanese's accountability values apply in "mantep-mantepan lan percoyo" wisdom or mutualism trust. Meanwhile, the Madurese perform accountability values in "oreng jujur bakal pojur" or honest man will get his luck. The value of local wisdom affinity is also carried out in profit sharing management. The Javanese and Madurese considerate accountability in cattle sharing system based on mutual support within parties involved and brotherhood establishment. The added value of the local wisdom tends to reduce the profits sharing risk obtained by the parties.
\end{abstract}

Keywords: accountability, cattle sharing, profits sharing risk.

\section{Introduction}

Indonesia's beef cattle potential reached 16, 6 million in 2017 (Directorate General of Livestock and Animal Health Services, 2018). East Java has the highest potential supply of beef cattle for national needs. It has contributed 103,625 head of cattle per year (Directorate General of Livestock and Animal Health Services, 2018). The beef cattle commodities consist of local cattle and limousine cattle. The regions that supply local beef are Sumenep Regency in Madura with 361,127 cows in 2017 (BPS-Statisitics Indonesia, 2018). While the limousine supply area, one of which is Jombang Regency, East Java. Both of these regions do not have a cattle breeding industry. Nevertheless, it occurs in the in-home industry form. Javanese and Madurese people used to recognize the mating and animals production offspring as cattle sharing. Javanese called cattle sharing "maro", while Madurese easily acknowledge this activity as "raksaan". Some other regions have various cattle sharing patterns relate to the characteristics differences. Previous research shows that the local cattle sharing system generates business profits in economic dimension (Marisa \& Sitepu, 2020; Sirajuddin et al., 2019Enrekang District by using quantitative and descriptive methods. The types of data were qualitative and quantitative from both primary and secondary sources, and the data analysis used was the frequency distribution and income analysis. The results show that characteristics of the respondents in the traditional system and the institution system are similar regarding age and livestock experience, but show differences in educational attainment, a number of family members, and the

Received: May 05, 2020, Revision: Desember 21, 2020, Accepted: June 08, 2021

Print ISSN: 0215-8175; Online ISSN: 2303-2499. DOI: https://doi.org/10.29313/mimbar.v37il.6009

Accredited Sinta 2 based on the decree No.10/E/KPT/2019 until 2024. Indexed by DOAJ, Sinta, Garuda, Crossreff, Dimensions 
commercial scale. Beef cattle farmers who follow the system of partnerships with the institution profit share system are mainly at secondary level (45.4\%; Prasetyono \& Rakhmawati, 2019; Wulanda \& Faizah, 2019; Siregar et al., 2018).

Domestic cattle sharing system is one of the local wisdoms that is still maintained to strengthen the household economy. Since Java and Madura have local beef cattle sharing, the economic potential could present. Cattle prices tend to rise from year to year (Directorate General of Livestock and Animal Health Services, 2018). If the exceedingly high need for meat is balanced with local economy's strength, it will create significant advancement for national economic growth (Smith et al., 2018). Several countries have started initiate developing cattle as an economic potential such as in Thailand (Bunmee et al., 2018), South Korea (Chung et al., 2018), United States (Drouillard, 2018), and South Africa (Mapiye et al., 2018).

The beef cattle sharing activity in Java and Madura involve profound local cultural virtue. Therefore, this cooperation requires involved parties to obey the local wisdom. In cows maintenance, the cattle breeder has an obligation to fattening the cows, whereas the other parties or cattle owners commit to providing good cattle (Utami et al., 2018) East Java, Indonesia. The research aimed to examine income of smallholder beef cattle farming and its influencing factors. The research used 30 members of the Pancong Jaya group farmer that obtained by purposive sampling method. Research regarded descriptive analysis using economic formulation and multiple regression technique. Results found that R2 Adjusted obtained $73.70 \%$ and F-calculation (12.625. Instead of using a formal declaration, the parties' cooperation is carried out on informal agreement's foundation. Despite the informal arrangement, local cattle sharing deem to conduct good business principles. One of the principles implemented is accountability, which represents a mutual belief system. Therefore, this local business is run based and being relied on honesty or truthfulness.

From an economic perspective, accountability refers to managerial control in business activity (Solomon, 2020; Brennan \& Solomon, 2008). Accountability is also a tool to protect the ownership and control of business entities (Han \& Perry, 2020; Hall et al., 2015). Accountability can be delivered managerially through performance and financial management objective setting and targets. Moreover, it also delivers through greater informatory accountability, formal conventions, and transparency (Matthews, 2015; Gains \& Stoker, 2009).

Accountability principles obligate the economic actors not only to pursuit profit but also the capacity to account for the process. The involved entities took responsibility in conducting reasonable and transparent profit sharing. In both traditional and modern economic activities, the accountability principle plays an important role since it becomes part of business effectiveness and company performance indicator (Filguerias, 2016).

In recent contemporary business activity, accountability can be found in particular maxims. In recent decades of public ownership, planning or centralized management have replaced private ownership, competition, and (quasi) market incentives (Thomann et al., 2018). The corporate shifting does not necessarily change the principles of business accountability.

Companies involved in the business are subject to a review in which third parties assess whether the company meets the principles and standards outlined by the stakeholders. Nevertheless, a point of intersection between those different traditions is the recognition that the regulators require a strengthening of accountability. This concept has become a vocabulary in contemporary business theory and has become the basic principle of accountability order. In turn, the requirements for accountability have strengthened another business principle that is transparency.

Moreover, in macroeconomic context, demand for strengthening the accountability system clearly demonstrates the need for greater transparency in government actions towards society. Therefore, establishing the transparency policy of contemporary business has become mandatory. In these terms, the regulator should promote an opening of the business system to make it more transparent and, in turn, more aware to public evaluation. The transparency policy clarifies the concept of accountability and the practical viewpoints supported by institutional design and company culture. 
The increasing delinquencies by some public members demand for a transparency policy so that the regulator and its agents can control the society. Moreover, the transparency concept, consequently, has become a common phenomenon in contemporary business, appearing in appropriate courses as an irrefutable fact. The transparency presents itself as a remedy for the fraud and corporate management failure. However, these term does not provide a normative basis for the concept of accountability. These two concepts are often used in interchangeable terms without grasping the differences and institutional problems they bring forth.

Furthermore, in a traditional context, accountability could be delivered on various platforms. In the Indonesian context, the presence of accountability principles is also carried out in traditional economic activities. Local people use local wisdom virtues to ensure the comfort of business participants. Certainly, these various traditional business activities are closely related to local customs and habits.

One form of the traditional economy that is still practiced today in Indonesia is cattle farming. Particularly, the cattle-raising farming is carried out using cattle sharing model. This traditional business takes the cattle or beef as a commodity.

As a smallholder beef value chain, the local beef cattle sharing has to employ particular business models (Asikin et al., 2020). In Yogyakarta, beef cattle sharing partnership system shows accountability in profit sharing analysis (Achmad et al., 2019). The pattern also conducted in Enrekang, Sulawesi (Sirajuddin et al., 2019)Enrekang Regency were used as the research sample. The research was descriptive, analysing primary and secondary data, qualitatively and quantitatively. The results showed that the age of the farmers who joined the system was in the productive age (95\%. In Kupang, the beef cattle sharing system contribute to many smallholder farm livelihood in rural areas (Nono et al., 2018).

Meanwhile, the structural program of beef cattle sharing is carried out through revolving system pattern (Farhan \& Firmansyah, 2017), SIPT program (Price et al., 2017), cattle sharing business in CSR programs (Popova et al., 2019; Soemanto et al., 2017; (Novra, 2015), micro-credit program (Mahendri, 2018), and Independent
Institution Group (LM3) which actively carries out beef cattle sharing program (Hadi et al., 2020).

Whereas, other regions in Indonesia conduct cattle sharing with an idiosyncratic pattern. Two areas that have traditional patterns in business for beef cattle sharing are Java and Madura. Those regions have perspectives, locality, and cultural relativity in custom and traits. The historical setting, local geographical potential, natural resources, institutional and traditional structural contribute to community locality values strengthening. Therefore, uniqueness in managing economic potential merge with good governance business, particularly in maintaining accountability, could be used to approach the cattle sharing system in Madura and Java.

The comparative advantages, economic profit sharing, and cultural holding each other in the Javanese and Madurese cattle sharing system stimulate and give rise to the heuristic research. Based on this extended accountability regimes framework, this research move beyond predominantly conceptual, discursive or normative approaches toward accountability to make the concept pragmatically. The research address two empirical questions. First, how do the Javanese and Madurese conduct the cattle sharing business? Second, are there particular accountability patterns raise from that traditional activity? The research explores how the Javanese and Madurese perceived accountability that maybe differ in hybrid contemporary business models. This two regions selection enables to compare the uniqueness of those who implement the same business. The fact that those two regions hardly hold informal accountability makes them a particularly telling case for local-oriented accountability. Based on the background above, the research configures a qualitative descriptive approach to depict the traditional cattle sharing and accountability principles conduct in Java and Madura.

This research explores the good governance principle in business and the locality embedded based on the background delivered above. This research emphasizes the accountability and dynamic interaction with the values of wisdom and practices of customs traditions. It is merely to reveal the local community's character, industry level, and motivation of participants in the beef cattle sharing system. Descriptive studies 
are carried out to understand better the locality accountability among beef cattle sharing systems in Madura and Java.

\begin{abstract}
nterdisciplinary understanding embraced incomprehension of findings and discussion of this research. Thus, an eclectic approach becomes an alternative method chosen to gain understanding and ethical and emic perspectives from several research findings. The eclectic approach enables researchers to see the reliability of interdependence among some dimensions (Cantwell \& Narula, 2001).
\end{abstract}

\section{Research Methodology}

This research employed case studies to gain an in-depth understanding of the research object. As a qualitative approach, case studies could explore the unique case found in empirical realities (Kamayanti, 2017). In research using this method, an indepth longitudinal examination of a situation or a case is carried out through systematic observation methods, collecting data, analyzing information, and reporting the results (George \& Bennett, 2005).
This research uses a single case study with one unit of analysis, which is accountability practice in local cattle profitsharing risk system. Research locations took place in Sumenep, Madura, and Jombang, East Java. Those specific regionals of case studies were chosen to get a habitual tendency to behave at the research site (Stake, 2005).

This research used a standardized open-ended interview to collect data. Such an interview method was applied to mimic informal conversation that encourages trust, openness, and information. The interview was conducted with ten informants (five cattle farmers and five cattle owners) to represent research subjects. It also allowed the farmers to initiate and elaborate on topics or solutions of importance to them without limitations instated by the research team's presumptions.

Observations were made entirely in the field of a cattle sharing program location. Observation guides were physical environment, farmers' activity, and profit sharing transaction. The research was done in five stages: determine research objective,

Table 1.

Research Method Process

\begin{tabular}{|c|c|c|}
\hline Stage & Procedure & Output \\
\hline $\begin{array}{l}\text { Research } \\
\text { objective }\end{array}$ & $\begin{array}{l}\text { Identifying a topic that lends to } \\
\text { in-depth analysis in a natural } \\
\text { context using multiple sources of } \\
\text { information: events, situations, } \\
\text { programs, or activities. }\end{array}$ & $\begin{array}{l}\text { Research object "emphasizes accountability and } \\
\text { dynamic interaction with the values of wisdom and } \\
\text { practices of customs traditions" }\end{array}$ \\
\hline $\begin{array}{l}\text { Research } \\
\text { Design }\end{array}$ & $\begin{array}{l}\text { Developing an indepth understanding } \\
\text { of a "case" or bounded } \\
\text { system }\end{array}$ & $\begin{array}{l}\text { Single case studies with one unit analysis: } \\
\text { accountability pratices in local cattle sharing system }\end{array}$ \\
\hline $\begin{array}{l}\text { Data } \\
\text { Collection }\end{array}$ & $\begin{array}{l}\text { Emphasizing time in } \\
\text { the field, multiple sources of } \\
\text { information, and collaboration. }\end{array}$ & $\begin{array}{l}\text { 1. Extensive information is gathered through open- } \\
\text { ended interview with ten informants. } \\
\text { 2. Observation concern to spesific guide: farmers } \\
\text { activity, physical environment, and profit sharing } \\
\text { transaction } \\
\text { 3. Documents from audiovisual materials and other } \\
\text { relevant source. }\end{array}$ \\
\hline Data Analysis & $\begin{array}{l}\text { Data are reviewed to develop an } \\
\text { overall } \\
\text { understanding. }\end{array}$ & $\begin{array}{l}\text { Case(s) is (are) described in detail and a context for } \\
\text { the description is } \\
\text { delimited. Key issues or themes about the } \\
\text { case(s) are developed. A cross-case analysis } \\
\text { is conducted if appropriate. }\end{array}$ \\
\hline $\begin{array}{l}\text { Reporting } \\
\text { Findings }\end{array}$ & $\begin{array}{l}\text { Reporting focuses on case } \\
\text { description, analysis, and } \\
\text { interpretation addressed differently } \\
\text { or equally. }\end{array}$ & $\begin{array}{l}\text { Consider the patterns in light of relevant literature } \\
\text { or other research; give appropriate explanation } \\
\text { (analysis) for research findings; relate the analysis to } \\
\text { the extant literature on the subject }\end{array}$ \\
\hline
\end{tabular}

Source: Researcher's compilation (2019) 
settle a case studies design, data collection, data analysis, and reporting findings. The research design refers to (Hancock \& Algozzine, 2017) case studies practical guide. The following Table 1 describes the research methods in more detail.

\section{Results and Discussion}

\section{Traditional Benefits Accountability in Madurese Local Cattle Sharing}

Madura, with its comparative geographical advantages, is an alternative regional to exposing cattle business. It settled the main islands and developed landbased communities on agriculture and then followed by animal husbandry, particularly beef cattle. The availability of forage on this island is one of the main factors that support the cattle business (Hadi et al., 2020). Two leading practices occur in Madura livestock cattle field: self-owned cows maintenance and cattle sharing maintenance. From the Madurese community's perspective, farmers who raise and own their cows run this cattle sharing business to help them plow their fields and lawn. It remains a convergence agriculture business that integrates agriculture and animal husbandry. From the agricultural side, the forage can be used to feed the cows which provide protein supply; while animal husbandry results in the form of cow muck that is used as compost manure and fertilizer for the fields.

Economic profit-sharing in this cattle sharing pattern is not regarded more important than another. Whereas, the cattle scale held in a household can meet farmer's domestic need's economic contribution relatively small with 1-2 scale compared to farmers' revenue (Tribudi \& Ristyawan, 2017).
Madura's cattle sharing program is recognized as "raksaan" or "oanan" which has a particular pattern that different from other regions. Beside two participants, there is a third party involved in Madura's cattle sharing system. The first participant is referred to investor or cattle owner, and the second participant is the livestock or cattle farmers. These businesses provide a 'trusted intermediary layer' between the investor and livestock farmers as well as the third party known as "Paneggu". That way, the role of intermediary (paneggu) becomes mandatory for integrity purposes. The Madurese employs "oreng Jujur bakal pojur" (honest people will be lucky) virtue in conducting accountability in this business. This proverb works in a broader dimension of the Madurese association perspectives to think and do the obligation. These valuable values form the basis of the term Madurese upholds the values of local wisdom since their ancestors were close to Islamic teachings and cultural traditions.

The integrity of a third party, known as the "orang jujur bakal pojur", became a fortune for the surrounding community. There is an opportunity for the wealth to provide capital investment through a middleman in an attempt to bring about an agreement with local farmers. For local (livestock farmers), it is also an opportunity to improve their ability in raising the cows and participate in this beef cattle sharing investment. This third party or paneggu play a vital role in finding the excellent cow to be raised by farmers. In this business, the paneggu competency in choosing the cow qualification is mandatory. There are some requirements embedded in cow selection, such as mediocre cow (not too fat and have large bones), upright cow feet ("tak rempa" in Madurese traits), has an oval head, red cow fur, has tight and

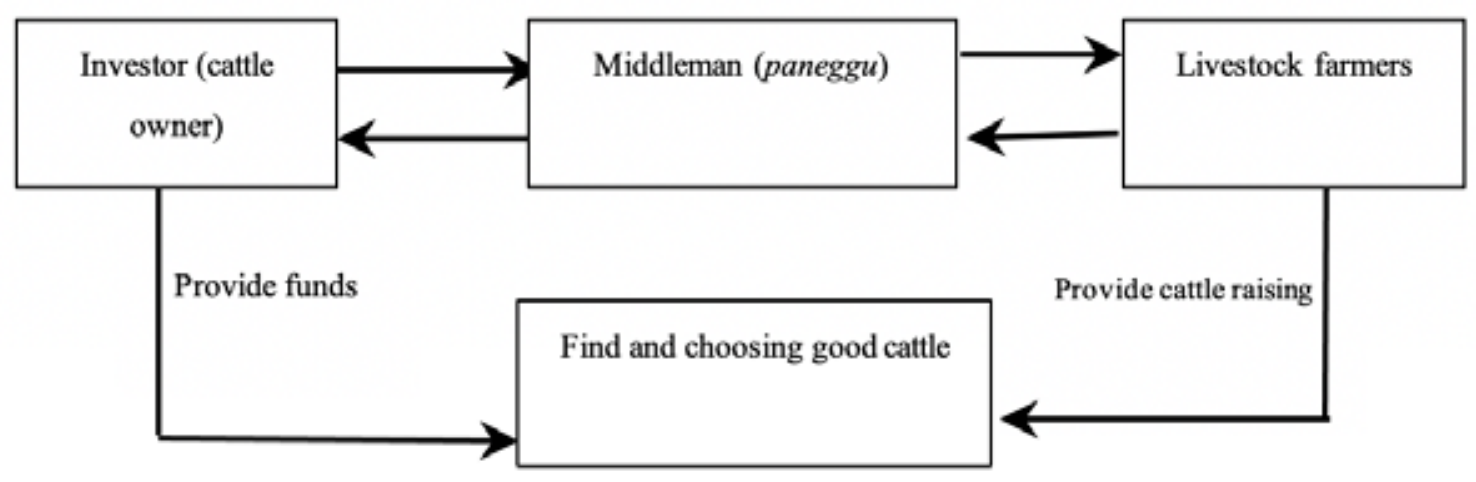

Figure 1. Beef Cattle System in Sumenep, Madura 
limp skin, has large ribs, has thigh attached tail, and has straight posture. The ability to choose a good cow or bull remains a good reputation and publicity for "paneggu". Furthermore, the good cow selected will be raised by breeders (livestock farmers) within 3-6 months of the process.

The investors put honesty principles and integrity as a consideration in choosing a middleman (paneggu). Since the business began, paneggu has an obligation to made cattle selection, cattle buying, and cattle selling. Paneggu arbitrates the relationship between investor (cattle owner) and livestock farmers (breeders). The investor will ask paneggu to find good cows to be raised and farmers who will raise them. Meanwhile, on the farmer's side, paneggu will look for and keep the excellent investor to form profitable business. Paneggu has the responsibility to regulate financial circulation in the process of buying and selling cows, including calculating the cow price and appropriate profit-sharing. Thus, sinvestor and farmers are business decision. The beef cattle sharing system in Sumenep, Madura is shown in the following Figure 1.

Paneggu reaffirmed their local reputation as a trusted person since their childhood. This standing reputation makes investors trust the paneggu to manage their cattle investment. One of the paneggu is Alwi. He has been a middleman since his teenage years. When he was 14 , he learned from older paneggu known as $\mathrm{H}$. Dawi. Alwi's competencies and ability in handling the business management and human relation confidently made him the most reputable paneggu in his region. People recognize Alwi as an honest paneggu both in investor and farmer>s perception. Alwi is known as paneggu with high degree of proficiency in searching and finding good cows (sape becce) for farmers to be easily raised (ta'kera buddhu). Alwi's prowess is a true example of the term "oreng jujur bakal pojur".

Madurese community breeder employs the "paneggu" term as a person in chief in cattle sharing system and attaches the "honest man will be lucky" values in practice. Breeder is the party that receives the mandate or responsibility to raise cattle. The breeder obligates to raise the cows: feeding and bathing them, cleaning the cage, and other jobs related. Although not under the "paneggu" and the owner's direct supervision, the breeders raise and treat the cattle sincerely as his. This awareness compiles breeder dignity as a responsibility principle in conducting business partnerships. The religious belief saying "if you plant, you will harvest" encourage mutual assistance in the beef cattle sharing system.

Beef cattle being raised with sincerity and love will grow bigger and healthier. Hence, the selling price will be high and profitable, which means the breeders will get more profit-sharing portion.

Periodically, the breeders report to paneggu things related to the responsibilities of cattle advancement. The breeder also delivers information to the cow owner about sick or injured cows, cows with slow growth, and other obstacles. In this way, the gentleman agreement engages that both the breeder and paneggu will not be blamed if the cow dies or results in losses. The existence of periodic reports made by paneggu to the owner will create trust among the parties involved. Therefore, in the Madurese beef cattle sharing system, paneggu plays a central and essential role.

\section{Javanese Accountability in Local Cattle Profit Sharing Risk}

For many years, the beef cattle sharing system has existed in Jombang (East Java). The former patronage in this business could resist environmental advancement. This pattern employs not only economic and financial dimensions but also a culture to contribute. Javanese culture is associated with the artifact and indicated by flexibility, gentle manner, and beneficial values. The internalization of culture has contributed to the stretching dimensions of the daily lives of Javanese people. In beef cattle sharing held in Jombang (East Java), the blend between business dimension and locality indicates good business collaboration. The investor or the wealthy contributes funds to the farmers in cattle sharing regulation. For lower-class farmers, the beef cattle sharing system brings economic benefits and household income. There is reciprocity beneficial in this cattle sharing business. For some farmers, being engaged with an investor relates to economic experience. For others, the profit in cattle sharing becomes their capital in raising the cows.

An interesting point found out in beef cattle sharing held in Jombang is the 
generosity among investors. Behind economic practices, there are altruistic values of work. In the Javanese landscape, helping others is mandatory alms. In cattle sharing practices in Jombang, generous investors put capital to join the business with philanthropy's motivation to help the lower class society. As (Wantasen \& Paputungan, 2017) found, the contribution of parties in cattle sharing is that farmers have advantages as labor, place ownership, and competencies in farming. While the investor has comparative financial advantages, the collaboration between those advantages could benefit local economy and sustainable livelihood. The cattle sharing ensued when parties share the same desires. The cattle sharing business agreement in Jombang began with "mentep-mantepan lan percoyo" or mutual trust steadiness. The cooperation was established when the parties already agreed about these mutual trusts.

In Jombang, beef cattle are fed greenforage and household-made feed which include wet green grass and green leaves. Artificial feed usually uses tofu pulp, rice bran, corn bran, salt, concentrate, and polar which are processed into one mixture. Farmers usually employ their family members in running this business with six until eight months of livestock maintenance. In this region, the types of cows commonly raised are limousine and PO (Peranakan Ongole); $\mathrm{PO}$ is a cross between Limousin and local Javanese cows. Market absorbs cattle price ranging between 15 million and 25 million/ cow. After raised well, the cattle price could go from 25 million to 35 million/cow. The ordinary beef cattle sharing held in Jombang can be seen in Figure 2 below.
Beef cattle sharing work with some regulations applied. In the previous stage, collaboration requires an agreement on rights and obligations. Therefore, investors commit to buying the cattle to be raised, while farmers bind with the maintenance which includes feeding, controlling the health of cattle, and cleaning the cage. The informant -Abdul- mentioned that profitsharing in beef cattle sharing business has already been discussed at the beginning of the collaboration, usually around $40 \%$ for investors and $60 \%$ for farmers.

When the agreement has been agreed upon, there is still a possible evaluation conducted in the cooperation. For instance, when the costs of maintenance increase, there will be deregulation to avoid losses from both parties. It is possible to make agreement repairing while business cooperation running. The agreement evaluation can be based on investor's considerations (owner of the cows) or farmers'. We can say that those engagements show a close relationship between investors and livestock farmers. This attachment established due to the received values of their ancestors. In this context, a verbal agreement can hold more than, or even entirely supersede, a written one. They consolidated their locality values of "mantep-mantepan lan percoyo" in the maintenance of business relationship. Most of the informants said they felt comfortable with their positions in the business. The Javanese had a chance to learn about their locality when they were involved with some agreement in this business. This Javanese beef cattle sharing remains to maintain the supportive environment by upholding its tradition and the spirit of brotherhood.

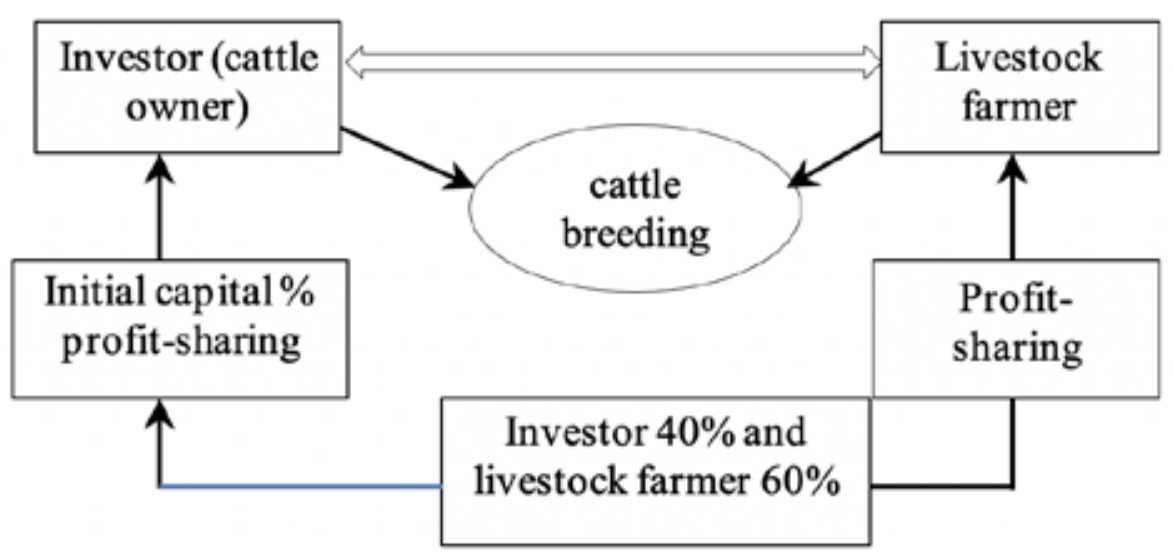

Figure 2.

Beef Cattle Sharing Pattern in Jombang, East Java 
In Jombang (East Java), beef cattle sharing was conducted between sub-districts but has no problem in running the sharing system. The substantial value of brotherhood and religiosity in the Javanese community contributes to their business relationships. Those systems upheld the principle of trust and moral engagement among the parties, even though the agreement between parties only performs in verbal statements without legal jurisprudence. As the informant Ahmad- said that the regulation of cattle sharing in Jombang was made to create positive mutual business relations. The investor and the farmers came from different villages or even different sub-districts but accepted the same beliefs and values: trust and integrity. In this context, culture facilitates a close working relationship between people in maintaining business activity.

Generally, Java's beef cattle profitsharing used a consent pattern. The parties (investors and farmers) agreed about the chosen ruminant that would be raised for several months ahead. In this region, people prefer bull (male cow) as a particular commodity that delivers "maro bathi" or a profit-sharing system in a commercial dimension. This mechanism employs capital gains as an indicator in deciding the revenue percentage that will be received by the owner and farmers. Usually, after 3-6 months of raising the cows, a final decision will be made according to the profit-sharing system where the proceeds from the sale of livestock will later be reduced by the cost of buying them. The difference in price earned is an income that will be shared between investors and farmers.

Madura and Java's common discussion explaining traditional involvement relates to accountability virtue held in traditional economic practices. This analysis benefits from the research findings of accountability principles. This research identifies two models that synthesize the debate on traditional economic dimensions in the onwards context and led by community-enhancing common interests. Although these two regions show a different pattern, they present local wisdom with an accountability approach. The use of community relations values interprets fulfillment of rights and obligations to entities involved in beef cattle sharing in Madura and Java. Two regions present the meaning of accountability by placing moral conduct axiology as a contributor.

Moreover, the objective of local wisdom values in those beef cattle sharing is to establish a cultural approach that can significantly affect human relations in developing an arduous process of learning how to live together and share. This pattern can benefit naturally from the historical analysis of cultural development and customs efforts that is not intended to be prescriptive but rather to reveal the value of local indigenous around the region as potential empowerment. It also means providing a better understanding of policy-makers with more alternative platforms to deal with community development in a related future.

Cattle farmers in Madura and Java obligate to convey the cattle fattening progress to investors. Communication between farmers and investors aims to reduce risks that could arise. If cattle are sick or about to die, farmers and investors can immediately decide to sell them or sell the meat to reduce the greater risk of cattle dying.

\section{Conclusions}

Based on research analysis and various literature confirmation, the accountability in Java and Madura's cattle business is interpreted as a form of joint responsibility for economic performance. Cattle ownership needs to improve and sustain local comparative advantages with warm relationship between owners and farmers. The accountability in profit sharing risk in Madurese is influenced by the "orang jujur bakal pojur "wisdom, whereas the Javanese. "mantep-mantepan lan percoyo" values could generate cattle sharing regulations. Furthermore, the locality has affected the shaping of local cattle sharing patterns. The locality seeks to organize its cross-border activities coherently in response to changing boundaries of the business dimension. This interdependence relation provides a framework that facilitates the best to consistent interdisciplinary approach synthesis. It helps choose between potentially competing perspectives and how to operate them.

Both in Madura and Java, the beef cattle sharing system are formed based on cultural values attachment and local wisdom. The parties involved in those traditional businesses use local traits and 
context in conducting good relationship management. The awareness to build good moral investment embedded in the accountability practices. In spite of the profit-seeking, this traditional business also pursues happiness and brotherhood. However, the underlying discussion can relate to accountability and locality relationships subject for future research. Therefore, maintaining accountability requires particular measurements that clarify its concept. Even more, such a measure can relate to accountability with greater emphasis on another variable/s. These findings point out to Madura and Java local wisdom's good performance targets that determine the accountability performance. The positive development of these relationships would lead to the enhancement of accountability for business performance.

\section{Acknowledgments}

We would like to thank the Institute of Research and Community Services at the Universitas Trunojoyo Madura for providing research grants. We would also like to gratefully acknowledge the informants and research assistants for their information and research assistance.

\section{References}

Achmad, F., Mulyo, J. H., Masyhuri, \& Subejo. (2019). Factors Affecting Profit Analysis of Small-Scale Beef Cattle Farmers in the Special Region of Yogyakarta, Indonesia. American-Eurasian Journal of Sustainable Agriculture, 13(June), 1-12. https://doi. org/10.22587/aejsa.2019.13.2.1

Asikin, Z., Baker, D., Villano, R., \& Daryanto, A. (2020). Business Models and Innovation in The Indonesian Smallholder Beef Value Chain. Sustainability, 12(17), 1-13. https://doi.org/10.3390/su12177020

BPS-Statisitics Indonesia. (2018). Jawa Timur Province in Figures 2018. BPS Provinsi Jawa Timur.

Brennan, N. M., \& Solomon, J. (2008). Corporate Governance, Accountability and Mechanisms of Accountability: an Overview. Accounting, Auditing \& Accountability Journal, 21(7), 885-906. https://doi. org/10.1108/09513570810907401

Bunmee, T., Chaiwang, N., Kaewkot, C., \& Jaturasitha, S. (2018). Current situation and future prospects for beef production in Thailand - A review. Asian-Australasian Journal of Animal Sciences, 31(7), 968-975. https://doi.org/10.5713/ ajas. 18.0201

Cantwell, J., \& Narula, R. (2001). The Eclectic Paradigm in The Global Economy. International Journal of the Economics of Business, 8(2), 155-172. https://doi. org/10.1080/13571510110051504

Chung, K. Y., Lee, S. H., Cho, S. H., Kwon, E. G., \& Lee, J. H. (2018). Current situation and future prospects for Beef Production in South Korea - A Review. Asian-Australasian Journal of Animal Sciences, 31(7), 951-960. https://doi. org/10.5713/ajas.18.0187

Directorate General of Livestock and Animal Health Services. (2018). Livestock and Animal Health Statistics 2018.

Drouillard, J. S. (2018). Current Situation and Future Trends for Beef Production in The United States of America - A Review. Asian-Australasian Journal of Animal Sciences, 31(7), 1007-1016.

Farhan, M., \& Firmansyah. (2017). Analisis Karakter Peternak Terhadap Tingkat Kepatuhan Mengulirkan Ternak Pada Pola Gaduhan Ternak Sapi Pemerintah Daerah Di Kabupaten Batang Hari. Jurnal Ilmiah Ilmu Terapan Universitas Jambi, 1(2), 106-120.

Filguerias, F. (2016). Transparency and Accountability: Principles and Rules for The Construction of Publicity. Journal of Public Affairs, 16(2), 192-202. https:// doi.org/10.1002/pa

Gains, F., \& Stoker, G. (2009). Delivering ' Public Value ': Implications for Accountability and Legitimacy. Parliamentary Affairs, 62(3), 438-455. https://doi.org/10.1093/pa/gsp007

George, A. L., \& Bennett, A. (2005). Case Studies and Theory Development In The Social Science. MIT Press.

Hadi, P. S., Rahayu, E. T., \& Pratiwi, A. N. (2020). Model of Empowerment Members of Farmers Group Based on Beef Cattle Business in Indonesia. International Journal of Sciences: Basic and Applied Research (IJSBAR), 52(1), 31-39.

Hall, A. T., Frink, D. D., \& Buckley, M. R. (2015). An accountability Account: A review and Synthesis of The Theoretical and Empirical Research on Felt Accountability. Journal of Organizational Behavior. https://doi.org/10.1002/ job.2052 An

Han, Y., \& Perry, J. L. (2020). Corrigendum to: Conceptual Bases of Employee 
Accountability: A Psychological Approach. Perspectives on Public Management and Governance, 3(4), 340-340. https://doi. org/10.1093/ppmgov/gvaa014

Hancock, D. R., \& Algozzine, R. (2017). Doing Case Study Research: A Practical Guide for Beginning Researchers (3rd Editio). Teachers College Press.

Kamayanti, A. (2017). Metodologi Konstruktif Riset Akuntansi: Membumikan Religiositas (A. D. Mulawarman (ed.)). Yayasan Rumah Peneleh.

Mahendri, I. G. A. P. (2018). Financing Small-Holder Cattle Fattering in Indonesia: Integrating Demand, Supply and Institutions [The University of Queensland]. In School of Agriculture and Food Sciences. http://iiard.com/ index.php/IJSSMR/article/view/1252

Mapiye, O., Makombe, G., Mapiye, C., \& Dzama, K. (2018). Limitations and Prospects of Improving Beef Cattle Production in the smallholder Sector: a Case of Limpopo Province, South Africa. Tropical Animal Health and Production, 50(7), 1711-1725. https://doi. org/10.1007/s11250-018-1632-5

Marisa, J., \& Sitepu, S. A. (2020). Beef Cattle Livestock Business Income Analysis in West Binjai District, Indonesia. Asian Journal of Advances in Agricultural Research, 13(1), 24-29. https://doi. org/10.9734/ajaar/2020/v13i130095

Matthews, F. M. (2015). Letting Go and Holding on: The politics of Performance Management in The United Kingdom. Public Policy and Administration, $O(0), 1-21$. https://doi. org/10.1177/0952076715615186

Nono, O. H., Natawidjaja, R., Arief, B., Suryadi, D., \& Kapa, M. M. J. (2018). The Impact of Sharing Arrangement Institution on Beef Cattle Breeding Performance in Kupang District, East Nusa Tenggara Province, Indonesia. IOP Conference Series: Earth and Environmental Science, 122(1). https://doi.org/10.1088/1755$1315 / 122 / 1 / 012135$

Novra, A. (2015). Subsidi subsidi Bunga Modal Yang Diterima Rumah Tangga Peternak Sapi Binaan Program CSR (Corporate Social Responsibilty) Petrochina Jabung Ltd. Agriekonomika, 4(2), 122-131.

Popova, O., Koval, V., Antonova, L., \& Orel, A. (2019). Corporate Social Responsibility of Agricultural Enterprises According To Their Economic Status. Management Theory and Studies for Rural Business and Infrastructure Development, 41(2),
277-289. https://doi.org/10.15544/ mts. 2019.23

Prasetyono, P., \& Rakhmawati, Y. (2019). Gaduhan: Madurese Traditional Cattle Sharing Program in Economic and Social Perspective. Advances in Social Science, Education and Humanities Research, 363(Icss), 24-27.

Price, B., Study, A. C., Nur, N., Fefta, A., \& Amin, F. (2017). Business Strategy of Cattle farmers and Bottleneck in Production under The Rise in Beef Price: A Case Study in Malang District. Jurnal Ilmiah Administrasi Publik (JIAP), 3(3), 214-222.

Sirajuddin, S. N., Hastang, Lestari, V. S., \& Rosmawaty. (2019). The Implementation of a Profit-Sharing System Between Beef Cattle Farmers and The Maiwa Breeding Centre in Enrekang, South Sulawesi, Indonesia. IOP Conference Series: Earth and Environmental Science, 260(1). https://doi.org/10.1088/17551315/260/1/012001

Sirajuddin, Sitti Nurani, Hastang, Lestari, V. S., \& Rosmawaty. (2019). Livestock Ecology Research on Institution and Traditional Sharing Systems in Cattle Farms. EurAsian Journal of BioSciences, 13(1), 239-244.

Siregar, A. R., Sirajuddin, S. N., Lestari, V. S., \& Fitrianti, N. (2018). Sustainability Strategy for Profit Sharing Systems for Beef Cattle Farmers with Institutions in Terms of Economic Aspects. Advances in Environmental Biology, 12(9), 2018file://C:/Users/EBC KOMPUTER/ Documents/ajas.1. https://doi. org/10.22587/aeb.2018.12.9.2

Smith, S. B., Gotoh, T., \& Greenwood, P. L. (2018). Current Situation and Future Prospects for Global Beef Production: Overview of Special Issue. Asian-Australasian Journal of Animal Sciences, 31(7), 927-932. https://doi. org/10.5713/ajas.18.0405

Soemanto, S. L., Kartono, D. T., \& Ratriyanto, A. (2017). The Empowerment of SmallScale Beef Cattle Farmer Households: Case Studies of Csr Ptpn Xii Program, East Java, Indonesia. ... Journal of Social Sciences and ..., 3(6), 27-36. http:// iiard.com/index.php/IJSSMR/article/ view/ 1252

Solomon, J. (2020). Corporate Governance and Accountability (Issue October). John Wiley \& Sons Inc. https://books.google. co. id/books?hl=en\&lr=\&id= JAX9DwAA QBAJ\&oi $=$ fnd\&pg $=P R 7 \&$ ots $=n x-Y \_x a Z$ 
13\&sig $=$ e5 JdnNM3CBity 1 duYn8EBVjkGo\&redir_esc $=y \# v=$ onepage $\& q \& f=$ false Stake, R. E. (2005). Case Studies. In N. K. Denzin, \& Y. S. Lincoln (Eds.), Handbook of Qualitative Research (pp. 443-454, 3rd ed.). Thousand Oaks, CA: Sage Publications.

Thomann, E., Hupe, P., \& Sager, F. (2018). Serving Many Masters: Public Accountability in Private Policy Implementation. Governance, 31(2), 299-319. https://doi.org/10.1111/ gove. 12297

Tribudi, Y. A., \& Ristyawan, M. R. (2017). Analisis Ekonomi Sapi Potong Pola Gaduhan: Studi Kasus di Desa Slorok, Kecamatan Kromengan, Kabupaten Malang. Jurnal Ekonomi, Bisnis Dan Kewirausahaan, 6(1), 30-48. https:// doi.org/10.26418/jebik.v6i1.20724
Utami, H. D., Yakin, A., \& Seruni, A. P. (2018). Determinants Affecting on Smallholder Madura Cattle Farming at Pamekasan Regency, East Java, Indonesia. IOP Conference Series: Earth and Environmental Science, 119(1). https://doi.org/10.1088/17551315/119/1/012063

Wantasen, E., \& Paputungan, U. (2017). Faktor-Faktor Yang Mempengaruhi Nilai Tambah Usaha Ternak Sapi Di Desa Tumaratas Kecamatan Langowan Barat. Jurnal Zootek, 37(2), 294-302. https:// doi.org/10.35792/zot.37.2.2017.16083

Wulanda, D. A., \& Faizah, S. I. (2019). Peran LMI Dalam Pemberdayaan Ekonomi Masyarakat Miskin Melalui Program Gaduh Ternak Barokah Di Kabupaten Trenggalek. Jurnal Ekonomi Syariah Teori Dan Terapan, 6(8), 1690-1705; 